\title{
Adapting to Online Learning in Higher Education System during the Covid-19 Pandemic: A Case Study of Universities in Sri Lanka
}

Sri Lanka Journal of Social Sciences and Humanities Volume 1 Issue 2, August 2021: 147-160 ISSN: 2773 692X (Online), 27736911 (Print) Copyright: (C) 2021 The Author(s)

Published by Faculty of Social Sciences and Languages, Sabaragamuwa University of Sri Lanka Website: https://www.sab.ac.lk/sljssh DOI: http://doi.org/10.4038/sljssh.v1i2.46

\author{
Haththotuwa, P.M.P.S. ${ }^{1}$ and Rupasinghe, R.A.H.M. ${ }^{1{ }^{*}}$ \\ ${ }^{1}$ Department of Economics and Statistics, Sabaragamuwa University of Sri Lanka, Belihuloya, 70140, Sri Lanka.
}

Received: 28 January, 2021, Revised: 26 April, 2021, Accepted: 20 June, 2021.

How to Cite this Article: Rupasinghe, R.A.H.M. and Haththotuwa, P.M.P.S. (2021). Adapting to online learning in higher education system during the Covid-19 pandemic: A case study of universities in Sri Lanka. Sri Lanka Journal of Social Sciences and Humanities, $1(2), 147-160$

\begin{abstract}
With the prevailing COVID-19 pandemic, university education is almost entirely done through the online system, since traditional education cannot be continued. Hence, it has become very important to find the best models and learning platforms for online teaching and the problems students are facing in this process. And also checking the possibilities and students' perspectives on moving to an online system are important. Therefore, there is a need to research and find out whether these objectives are being met. The data were collected through an online survey and which covered the public and private universities in Sri Lanka, and the conclusion is based on the more than 900 responses received from undergraduates. The study discovered that university students most commonly use smartphones and laptops for online education and are connected to the Internet through smartphones via hotspots. The University Learning Management System (LMS) and Zoom also became popular learning platforms among them for conducting online lectures. The study also discovered that a high percentage of students liked to use these types of online learning in the future after the commencement of the university via the university LMS and Learn-Zoom free versions. But, the problem with access to the Internet due to the lack of internet coverage in certain areas is the main challenge they are faced with. However, the research advises that it is time to resolve the issues realized by the above findings for the benefit of future online learning and to carry out such educational activities without interruption.
\end{abstract}

Keywords: COVID-19, Higher education, Learning platform, Models, Online learning

\section{INTRODUCTION}

The COVID-19 pandemic is now raging worldwide. As a result, many lives have been lost and a large number of people have become infected (Plancher et al., 2020; Hodges et al., 2020). As a result of that economy, tourism, education and foreign affairs have been hampered in almost all countries of the world. The governments avoid gatherings of people and control the distance among people (Binti Hamzah et al., 2020). This has had a major impact on the education sector and has severely hampered its activities. Therefore, it is necessary to restart the educational activities under the measures taken to prevent the spread of the plague (MerklDavies, Doris M.; Brennan, 2001; Moorhouse, 2020; Putri et al., 2020; Yan et al., 2020). The activities of education cannot be held traditionally now since the COVID-19 pandemic is spreading (Binti Hamzah et al., 2020). As such, education has already commenced in universities and schools through the online education system (Alipio, 2020; Trung et al., 2020).

In Sri Lanka, higher education was done through the traditional educational system before this pandemic situation. Because of that, there is no existing popular method among undergraduates and staff for online education. University LMS is used as one of the platforms in some universities. And also Emails, Google groups, and Google drive is used for sharing lecture materials, references or exercises.
WhatsApp, Viber, Messenger, and Skype were popular among Sri Lankans, but they did not use them for online learning purposes.

One of the main issues that arise in the education sector is how to effectively teach university students online. Hence, by understanding different models and learning platforms they can be used for this online learning and teaching process. There is a paucity of research on this issue both in the world and in Sri Lanka during this Covid-19 pandemic. Especially, we could find very few published researches or surveys based on online learning, flexible models, and learning platforms during this Covid-19 pandemic in Sri Lanka. Not only that most of the researches in Sri Lanka and outside Sri Lanka only focuses on doing surveys and finding suitable models and platforms for online education. But in our research, we also focused on the problems students are facing when they are using online learning and suggested solutions for those problems. Therefore, there is a great need for surveys to fill this research gap. In this study, we paid special attention to the issues faced by university students when they engage in online university education.

There are similar studies have been identified from other countries and most of the countries are moving to online education through this pandemic situation. As a developing

\footnotetext{
* Corresponding author: Tel.: +94 (71) 832 4740; Email: hmrupasingha@gmail.com

iD https://orcid.org/0000-0003-3922-4290
} 
country, Sri Lanka needs to think a lot of things about this educational change. Specially Sri Lankan education is a free education system and different educational policies are there. Because of that moving to online education without interrupting a free education system is important. Currently, Learn-Zoom and University LMS are highly giving contributions for this purpose. Digital literacy and English language skills are other factors that need to be considered for this educational change in Sri Lanka. It is important to avoid dissimilarities among students. If we are planning to continue this online education, economic growth, infrastructural development in the country also needs to be considered.

Research data was collected through an online survey from university students in Sri Lanka. The final dataset is 909 responses collected via Google form and both government and private university undergraduates have participated. Multiple regression analysis was performed using the MINITAB software to analyze the collected data. Based on the analysis results we identified the different items and models, internet access methods, learning platforms, sharing methods of lecture materials. And also the students' problems, interest in online learning, and their preference for learning platforms for their future studies were identified and discussed and suggested solutions for their problems as well.

Our study tried to find answers to these types of current issues through an online survey among the students in the public and private universities in Sri Lanka. Further, the information on this survey is very important for the decisionmakers in the education sector for future educational activities.

The remainder of the paper is organized as follows. In Section 2, we discuss Literature Review. Section 3 discusses the Research Problem and Motivation and Section 4 introduces the Research Approach and Methodology. Section 5 is devoted to Results and Discussion. Section 6 concludes and discusses implications for future work.

\section{LITERATURE REVIEW AND HYPOTHESIS}

This COVID-19 virus spread mainly through respiratory droplets and intimate relationships (Binti Hamzah et al., 2020; YukiKogyo Co.Ltd, 2019). COVID-19 has already far surpassed the number of total cases and fatalities of its nearest viral comparators, SARS and MERS (Murphy, 2020; Zu et al., 2020). However, in addition to supportive care, no specific treatment has been established for COVID-19 (Yan et al., 2020; Binti Hamzah et al., 2020; Yang et al., 2020). To date, only CT scan findings have been recommended as major evidence for clinical diagnosis of COVID-19 in Hubei, China ( $\mathrm{Zu}$ et al., 2020; Hou et al., 2020)

This has had a major impact on the education sector and has hampered its activities. COVID-19 pandemic has resulted in the total closure of schools in about 192 countries all over the world with $91.4 \%$ of the total number of enrolled learners in these countries temporarily forced out of school (UNESCO, 2020). Higher Education in Sri Lanka most of the educational activities were done through the traditional education system. Therefore, the problem of how to continue education under such circumstances has now become a global issue (A et al., 2020). As a result, there is a greater focus on online courses that usually offer no face-to-face encounters for most or all of the contents (Allen et al., 2016; Allen \& Seaman, 2014; Platt, 2003; Allen \& Seaman, 2006; Morse, 2007). With the advent of technology, online education is becoming more and more popular. That is, the online system is also used for learning in higher education institutions.

In (Mulenga \& Marbán, 2020), researchers' goal is to study how the University of China manages that covid-19 risk through firstly they have blocked the opening of universities and schools. In (Allo, 2020), the objective of the researchers in this study is to investigate the learners' perception of online learning amid the COVID-19 pandemic. The results of this study show that the learner's understanding of online learning during COVID-19 is good. It is commendable that during the pandemic, they realized that such an online course was worthwhile and acted accordingly. In (Trung et al., 2020), this research was conducted on the Dataset of Vietnamese student's learning habits during COVID-19. The data obtained from that research, Students' habits are compared under normal circumstances and unusual circumstances such as a pandemic. The conclusions drawn from it can give an idea of how the future educational process should be. In (Basilaia, \& Kvavadze, 2020), the researchers conducted the study to check the tendency of schools to switch to online education during the Corona pandemic in Georgia. This research is based on a private school in Georgia and it is conducted to measure the quality of the online education system.

Like that there are some existing researches done in different countries in the different pandemic situations based on online education. The study (Hayashi et al.,2020) was based on a survey among state and nonstate university students in Sri Lanka. We could find very few published works or surveys conducted inside Sri Lanka regarding the possibility and learning models and platforms of online learning. Therefore, there is a great need for surveys to filling the research gap. The time has come to seriously consider online learning which can be very helpful to continue educational activities even under this type of pandemic situation.

\section{RESEARCH PROBLEM AND MOTIVATION}

There are various pandemics and crises like the COVID-19 pandemic such as SARS and MERS. Due to the COVID-19, most of the countries have applied lockdown and keep strict social distancing methods. Failure to continue education in this traditional manner would create a major setback in the education sector of the country (Basilaia, 2020; Plancher et al., 2020). That is why universities are shifting to an online education system (Alipio, 2020; Hodges et al., 2020).

Also, there is a possibility of natural disasters such as volcanic eruptions and typhoons in the future. In (Hodges et al., 2020), the researchers focus on the need for Emergency Remote Teaching (ERT) and point out the importance of doing it safely by switching to online education. Furthermore, this test shows that asynchronous activity is more appropriate than synchronous activity. The reason for this is asynchronous activities can reduce the inconvenience to students through technical issues. Also, the student, as a lecturer and administrator, must develop the skills needed to engage in online education. This research also focuses on a preplanned online course. But our research focuses on how to approach online education in the current context and how to focus on online education under a previously unprepared situation. And our research focuses on the need for online education and the problems encountered there.

One of the main issues that arise is whether this trend is very successful or not. So, it is very important to use learning models and learning platforms for online learning and measure their effectiveness (Moorhouse, 2020; Trung et al., 
2020). It is necessary to research the effectiveness and success of online learning and issues that students are faced with through this process (Allo, 2020).

Further, Sri Lanka as a developing country it is important to check the feasibility of using E-learning in higher education and we could not find any published work or survey conducted inside the country regarding this topic. Important of filling the research gap is motivated us to conduct this research.

Therefore, the time has come to get into deep consideration about E-learning which can be very helpful to continue educational activities even under this type of pandemic situation. Sri Lankan education system based on the traditional method that is continued for a long time. So, to shift from that traditional system to an E-learning system, it is necessary to research the effectiveness and success of E-learning and issues that are facing students through this process. That will be helpful for the government, universities, and other educational institutes to take decisions, make policies, organized learning, and introduce new degree programs based on the results of researches, there is a paucity of research on this issue both in the world.

\section{RESEARCH QUESTIONS}

It is become important to understand the feasibility of adapting to e-learning in the Sri Lankan higher education system during the COVID-19 pandemic and according to the above problem statement, the following research questions were defined.

RQ1: What is the usage of online learning before the COVID-19 and during the COVID-19 pandemic?
RQ2: What are the items, mode of connecting to the internet, learning platforms, and type of sharing lectures/materials used for online learning?

RQ3: What are the students' problems they are facing when using online learning and what are the solutions?

RQ4: How is the student's preference for online learning in the future?

RQ5: What are the students' perceptions of future online learning platforms/items?

\section{RESEARCH OBJECTIVES}

\section{Primary Objective:}

To identify the feasibility of adapting to e-learning in the Sri Lankan higher education system during the COVID-19 pandemic

\section{Specific Objectives:}

R01: Identifying the usage of online learning before the COVID-19 and during the COVID-19 pandemic

RO2: Identifying the items, mode of connecting to the internet, learning platforms, and type of sharing lectures/materials used for online learning

RO3: Identifying the students' problems, they are facing when using online learning and solutions for those problems RO4: To provide recommendations for the student's preference for online learning, their perception of future online learning platforms/items, and identifying strengths/positive impacts of online learning.

Figure 1 illustrates the mapping of research questions to research objectives which support achieving the main objective of the research by answering research questions.

Figure 1: Mapping of research questions to research objectives

\begin{tabular}{|c|c|c|}
\hline $\begin{array}{l}\text { Problem Statement: } \\
\text { It is become important to understand the } \\
\text { feasibility of adapting to e-learning in Sri } \\
\text { Lankan higher education system during the } \\
\text { COVID-19 pandemic } \\
\qquad \text { Retrieved from }\end{array}$ & & $\begin{array}{l}\text { Main Objective: } \\
\text { To identify the feasibility of adapting to e- } \\
\text { learning in Sri Lankan higher education system } \\
\text { during the COVID-19 pandemic } \\
\qquad \text { Achieved all }\end{array}$ \\
\hline $\begin{array}{l}\text { Research Questions } \\
\text { RQ1: What is the usage of online learning } \\
\text { before the COVID-19 and during the } \\
\text { COVID-19 pandemic? } \\
\text { RQ2: What are the items, mode of } \\
\text { connecting to the internet, learning } \\
\text { platforms and type of sharing } \\
\text { lectures/materials used for online } \\
\text { learning? } \\
\text { RQ3: What are the students' problems } \\
\text { they are facing when using online learning } \\
\text { and what are the solutions? } \\
\text { RQ4: How is the student's preference for } \\
\text { online learning in the future? } \\
\text { RQ5: What are the students' perception } \\
\text { on future online learning platforms/items? }\end{array}$ & & $\begin{array}{l}\text { Specific Objectives } \\
\text { RO1: Identifying the usage of online learning } \\
\text { before the COVID-19 and during the } \\
\text { COVID-19 pandemic } \\
\text { RO2: Identifying the items, mode of } \\
\text { connecting to the internet, learning platforms } \\
\text { and type of sharing lectures/materials used } \\
\text { for online learning } \\
\text { RO3: Identifying the students' problems, } \\
\text { they are facing when using online learning } \\
\text { and solutions for those problems } \\
\text { RO4: To provide recommendations for the } \\
\text { student's preference for online learning, their } \\
\text { perception on future online learning } \\
\text { platforms/items and identifying } \\
\text { strengths/positive impacts of online learning. }\end{array}$ \\
\hline
\end{tabular}




\section{RESEARCH APPROACH AND METHODOLOGY}

\section{Scope of the Study}

Sri Lankan public and private university undergraduate students have been identified as the scope of the study. It included science and non-science institutions which offer degrees based on different subject areas. Undergraduate girls and boys representing all study years provided their responses.

\section{Data collection}

The survey covered the public and private universities in Sri Lanka and the conclusion is based on the more than 900 responses received from undergraduates. There are selected science and non-science universities that are under the purview of the University Grants Commission in Sri Lanka and other selected government and private universities are also included, which offer courses based on various disciplines. An online questionnaire had to be prepared as it was not appropriate to go to university students and collect data in the current situation. The questionnaire was developed through Google form and shared online for data collection. These

Figure 2: Different factors considered in the survey questionnaires covered the questions such as how university students engage in online education, methods, and platforms the lecturers use to deliver their lectures, and also included questions about the problems that university students face when they pursue online education and their perceptions on using online learning in the future. The number of questions was limited to 26 . The questions should be designed to cover all the objectives of the study. This questionnaire only includes close-ended questions for the convenience of the respondent.

Figure 2 explains the different six factors that were considered in the survey via the different questions.

The survey identified concerning this research such as educational factors, technical factors, economic factors, social factors, demographic factors, and psychological factors, is positively influencing the trend towards university online education during the Corona period.

Because of the difficulty in the physical distribution of questionnaires, the data collection was conducted only using Google forms online. But as we identified through the study there are several barriers to online access. Because of that, in our study, this data collection method has limitations.

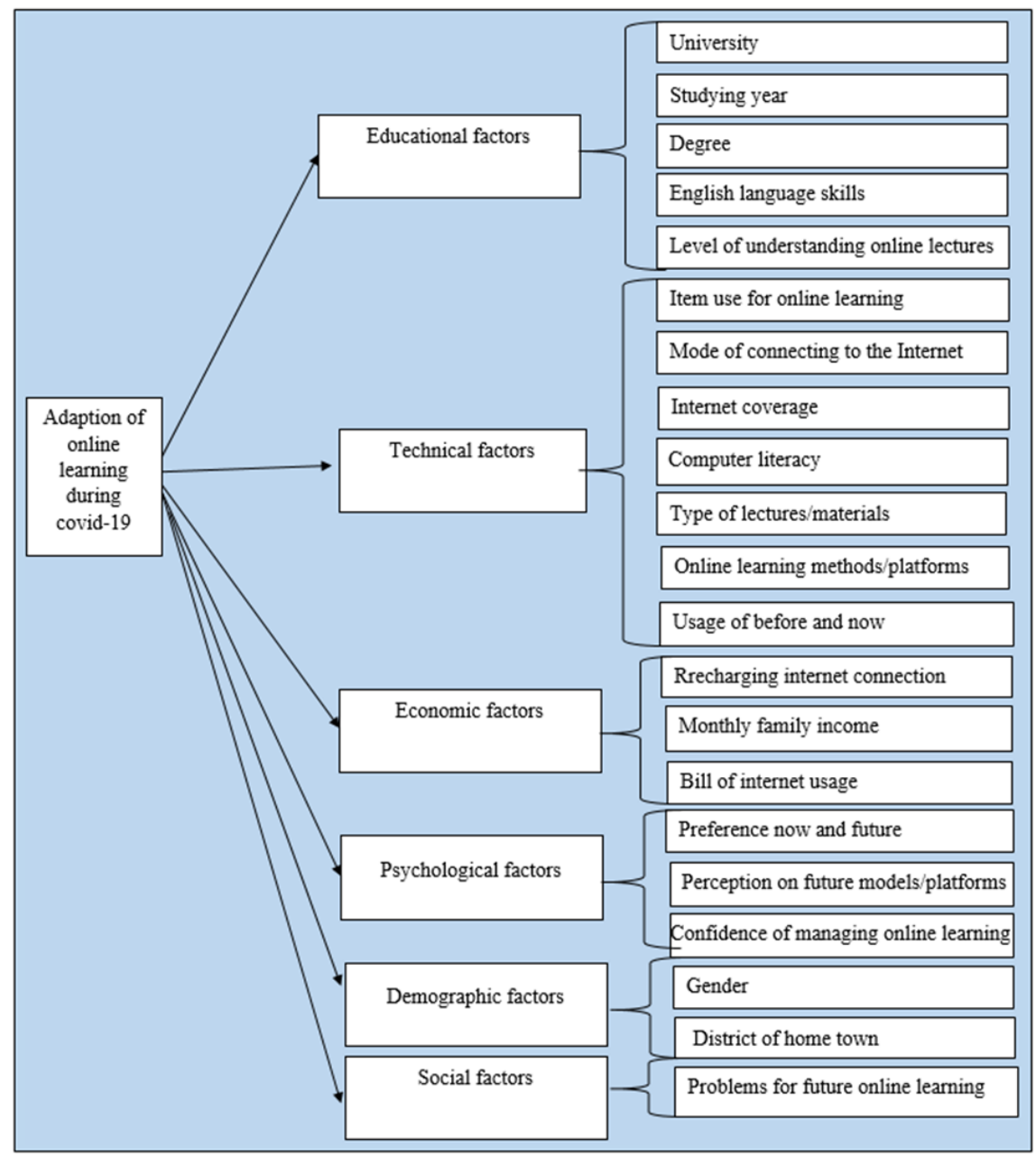

\section{Data Analysis}

First, we have selected sample data set without bias using a statistical approach such as simple random sampling. It is one of the most effective methods that can be used to avoid sampling bias, in which samples are chosen strictly by chance.
Then the most important part is to analyze the collected data across the field concerning a particular research method using a statistical technique. Logistic regression is used to analyze the data relevant to this study. MINITAB data analysis software was used for this regression analysis. Further findings and recommendations were based on the data analysis results. 


\section{RESULTS AND DISCUSSION}

Here, data from 909 samples of university students were obtained, representing the entire university system. Presents in detail the behaviors of the information related to the subcategories of respondent information, models, and learning platforms used during the covid-19 pandemic, problems students face, and students' perception of online learning in the future.
As shown in Figure 3, the highest percentage (nearly 68\%) in the sample is represented by graduates studying non-science subjects. Among the students studying science subjects, students studying IT and Technology subjects are 19\% as represented by the sample, while $13 \%$ of the students studying Biology and Mathematics are represented in the sample. However, more than 100 students from all categories are represented.

\section{Respondent Information}

\section{Figure 3: Respondents' degrees}

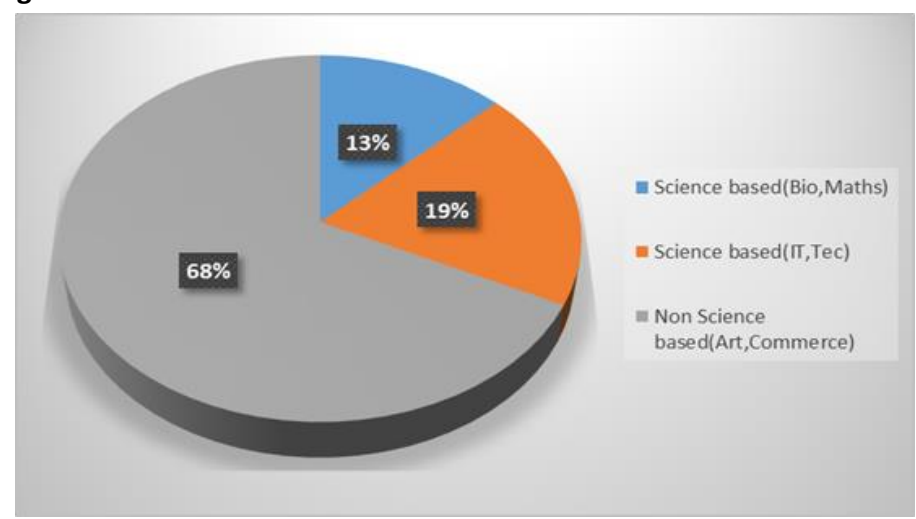

As shown in Figure 4, out of the sample, $77 \%$ are female students. It has 697 students, while $23 \%$ of the samples are male students, numbering 212. But, we have selected the final sample data set using a simple random sampling statistical approach. It helps to avoid gender bias in this sample.

Figure 4: Respondents' gender

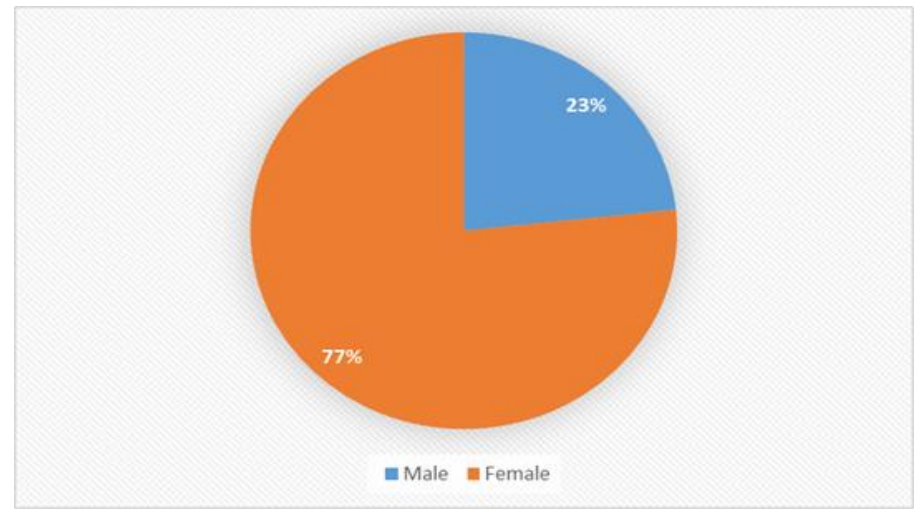

As shown in Figure 5, when the sample recipients' years of learning were focused upon, $50 \%$ of them represent third- year students, while second and fourth-year university students make up $20 \%$ and $23 \%$ of the total sample, respectively. First-year students represent $7 \%$ of the sample. However, more than 50 university students represented all years.

Figure 5: Studying year

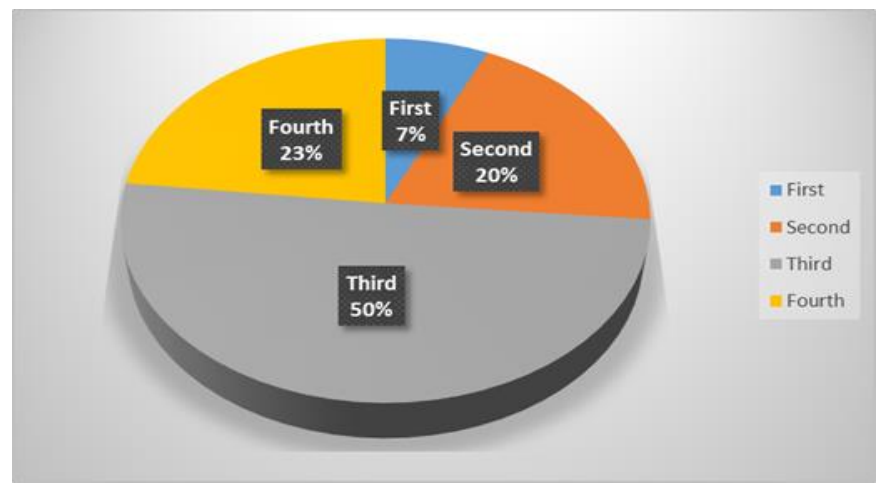


As shown in Figure 6, Most of the sample recipients live in Gampaha and Colombo District. However, the research represents 16 districts inhabited by more than 10 sample recipients, as illustrated by Figure 6 .

\section{Figure 6: District of respondents' home town}

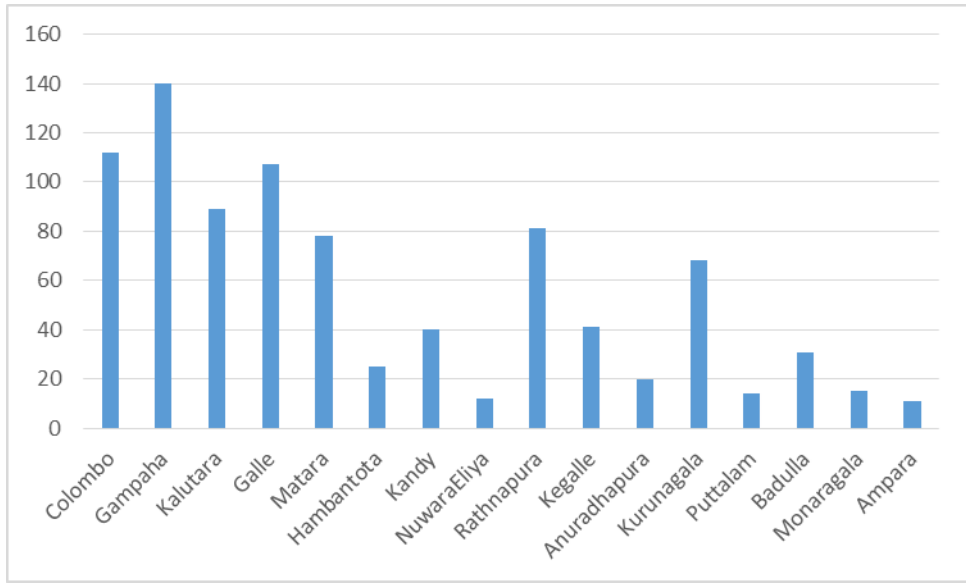

\section{Models and Learning Platforms Used During the COVID-19 Pandemic}

According to Figure 7 (a), before the Corona pandemic, 18\% of university students used online education at a high level. According to Figure 7 (b), during the Coronavirus pandemic, $71 \%$ of university students used mostly online education.
Also, $22 \%$ of the students on average were involved in online education. The lowest percentage of university students who used online education is only $7 \%$. According to Figure 7 (a) and (b), the high usage of online education by university students during the coronavirus pandemic is $53 \%$ more than before. And According to Figure 7, we can see that that it is increased up to $71 \%$.

Figure 7: Usage of online learning: (a) before the COVID-19, (b) during the COVID-19

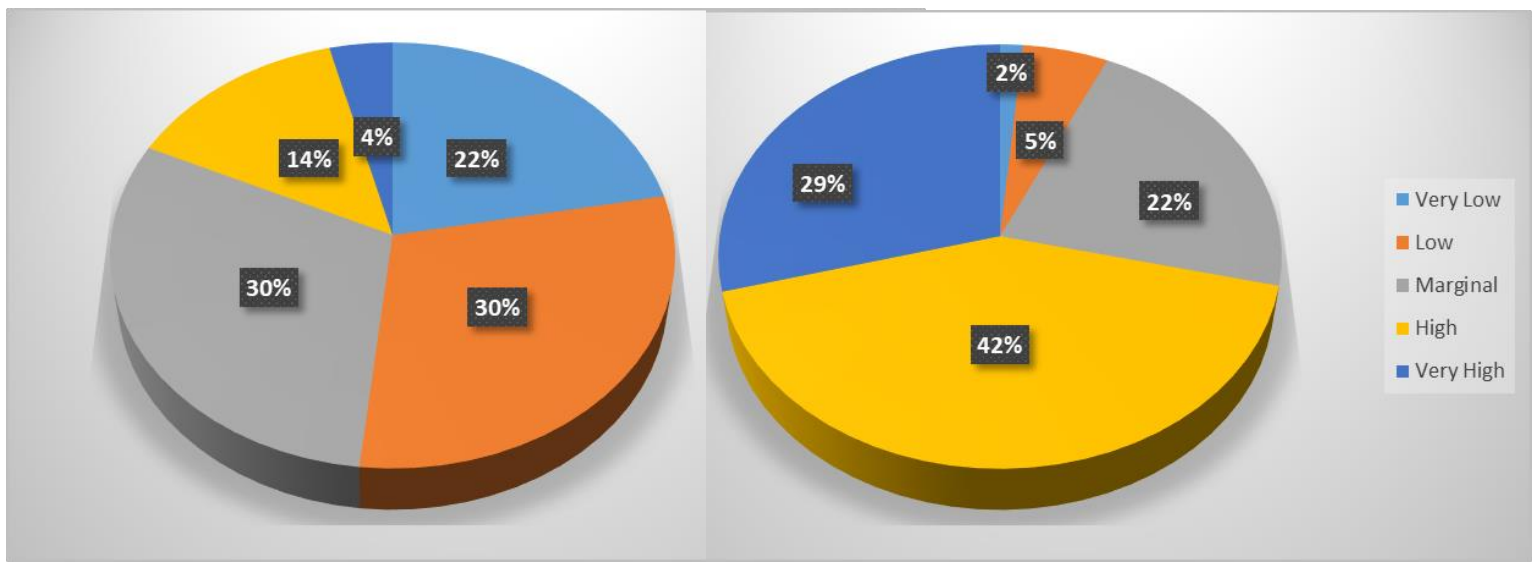

Among the responding university students, $85.6 \%$ have used smartphones and $65.1 \%$ have used laptops for online learning. Figure 8 describes the frequency of usage. A few of the students have used desktop, laptop computers, and tablets for online learning. We gave them the opportunity of selecting more than one option since students used more than one item for online learning during this Covid-19 period.

Figure 8: Items used for online learning

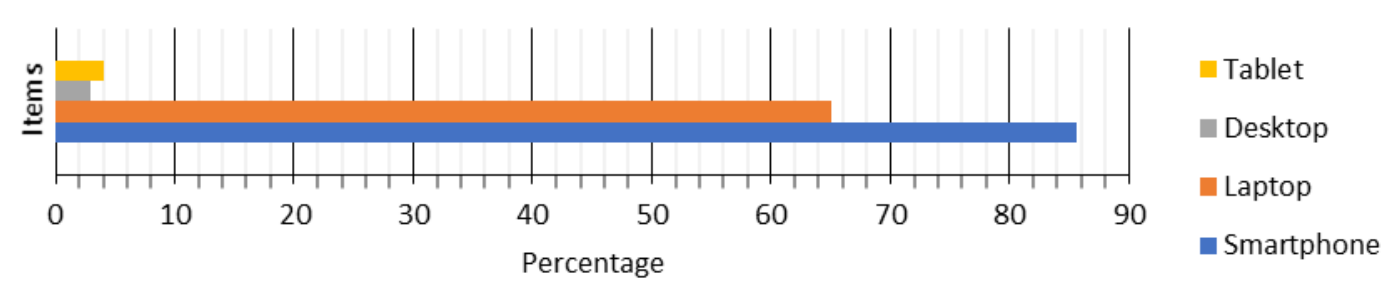


Then we checked the mode of connecting to the Internet and here too the students used more than one model of internet connection. As shown in Figure 9, most of them connected to the Internet through smartphone hotspots (61.2\%) while a considerable number of students used Wi-Fi
(48.6\%). A few respondents stated that they are using a dongle (9.4\%), ADSL (3.6\%), and wired connection (2.5\%) to connect to the Internet. It means that most of them connected to the Internet through a smartphone, such as a hotspot.

Figure 9: Mode of connecting to the Internet

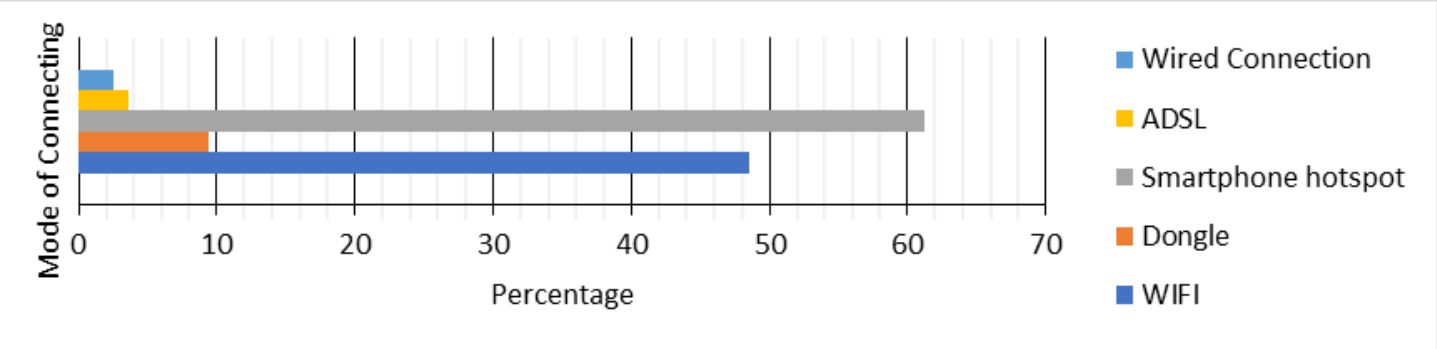

Also, during the COVID-19 pandemic, university students have increased the usage of university LMS (69.4\%) and Zoom as their learning platforms, as shown in Figure 10. There are $63.8 \%$ of students who utilized the Zoom payment method and $42.7 \%$ of students engaged through the Learn-
Zoom (free usage) - a Zoom learning platform. Also, according to the responses of the students, WhatsApp (57.2\%) usage becomes high for online learning during the COVID-19, while the survey found Email, Google group or Google link (43.1\%), Google classroom (19.6\%), Microsoft Teams (7.2\%), and less than $4 \%$ of Viber, Messenger, and Skype usage.

Figure 10: Learning platforms used during the COVID-19 pandemic

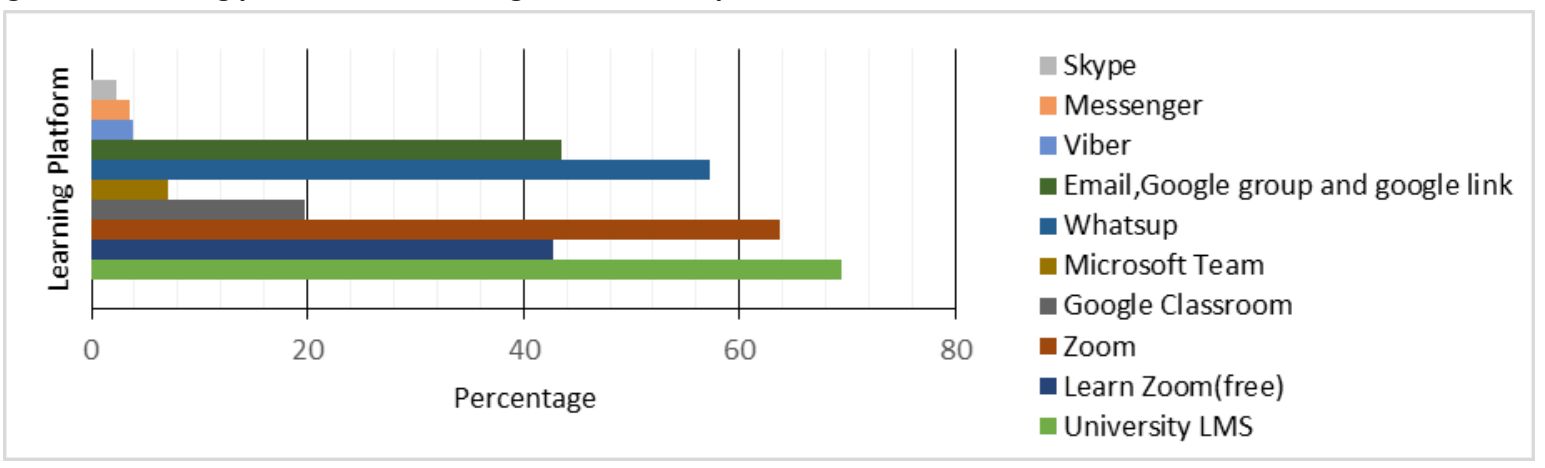

As shown in Figure 11, university lecturers often conducting online lectures $(83.8 \%)$ and sharing lecture notes using a

Figure 11: Type of sharing lectures/materials

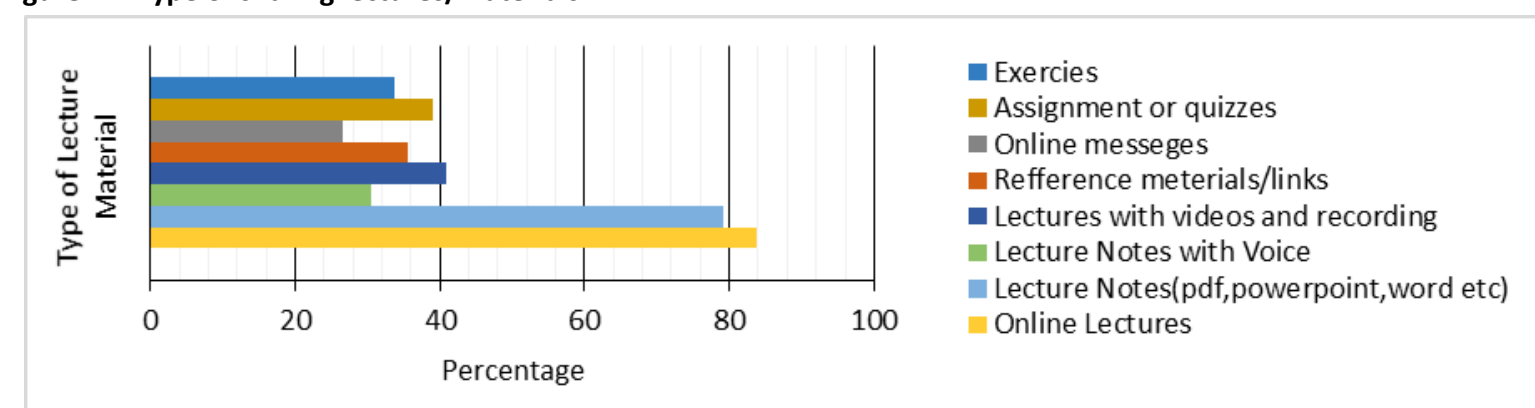

PowerPoint/PDF/Word app (79.2\%) are at a high level, in delivering materials of their lectures. And $41 \%$ of lecturers share lectures with videos or recordings, while some other lecturers' sharing methods are also popular among lecturers and students as described in Figure 11. 
Figure 12: Students' problems when using online learning

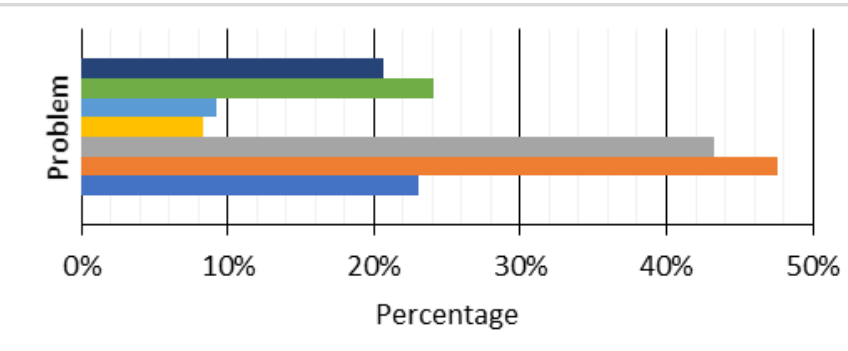

\author{
- No problem \\ - Financial problem \\ Language problem \\ n Poor computer/Technological skill \\ n Poor Internet coverage(No signal in my area) \\ - Internet access problem(WIFI,Dongle) \\ n Equipment problem(Destop,Laptop etc.)
}

And $78 \%$ of all university students face at least one such problem with their future online education. Furthermore, this research has revealed that the majority of the students who face difficulties in engaging in future online education face more than one problem with online education.

This research revealed that students engaging in online education face other problems in addition to those represented in Figure 12 above. One of the problems that can be identified in the analysis of the other issues is that the student is reluctant to listen to the lectures as there is no active connection between the teacher and the student through online education. Another problem that students are faced with in this method is their inability to ask questions as soon as any particular problem arises during the lessons.

Furthermore, students who study these subjects believe that online education is not at all compatible with learning language subjects and subjects with practical assessments. They also point out that online streaming of such subjects may limit the students' knowledge and understanding of the particular subject.

They also point out that online education is a major obstacle to the development of students' social skills. Students point out that the lack of knowledge, understanding, and experience gained through group activities is a huge problem here.

It is therefore essential to address these issues when making decisions regarding online education in the aftermath of the coronavirus pandemic.

Furthermore, the students' comments in this analysis show that students participate in online education while they are engaged in other activities as well. And in some cases, students are referred to online education without sitting in an educational environment. As a result, there is less focus on student education. Therefore, the students believe that educational activities are not being carried out effectively through this system.

Another problem is the disruption of online education in the event of bad weather and power outages.

Hence, it is clear from this research that university students also face the above problems that had not been focused upon primarily. It is therefore imperative that decision-makers on online education pay careful attention to these issues. As shown in Figure 13, generally the current Internet coverage is good as $51 \%$ of the respondents have approved it. Also, $31 \%$ of the respondents said that current Internet coverage is marginal, while $18 \%$ of the respondents were dissatisfied with the current Internet coverage. Accordingly, $82 \%$ of respondents were satisfied with the current Internet coverage.

\title{
Figure 13: Current Internet coverage in the hometown
}

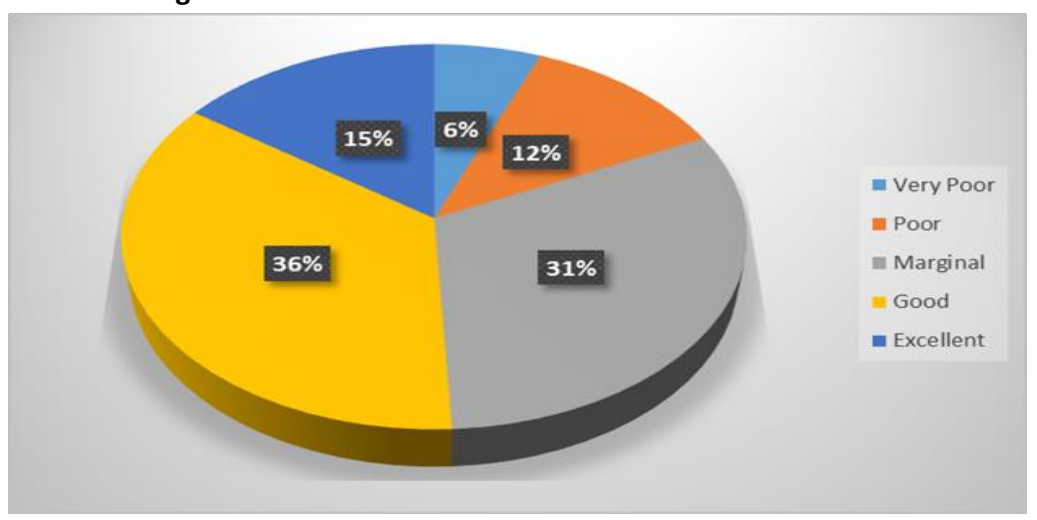

Students who faced the problem of frequently recharging their Internet connections, as well as those who had no current problems in recharging their Internet connections together, accounted for $31 \%$ of the total sample, while $38 \%$ of the students thought that it is normal to face current problems with recharging internet connection. According to the research, there is a $50 \%$ chance of problems with recharging Internet connections. Figure 14 explains the situation of recharging Internet connections. 


\section{Figure 14: Problems with recharging Internet connection}

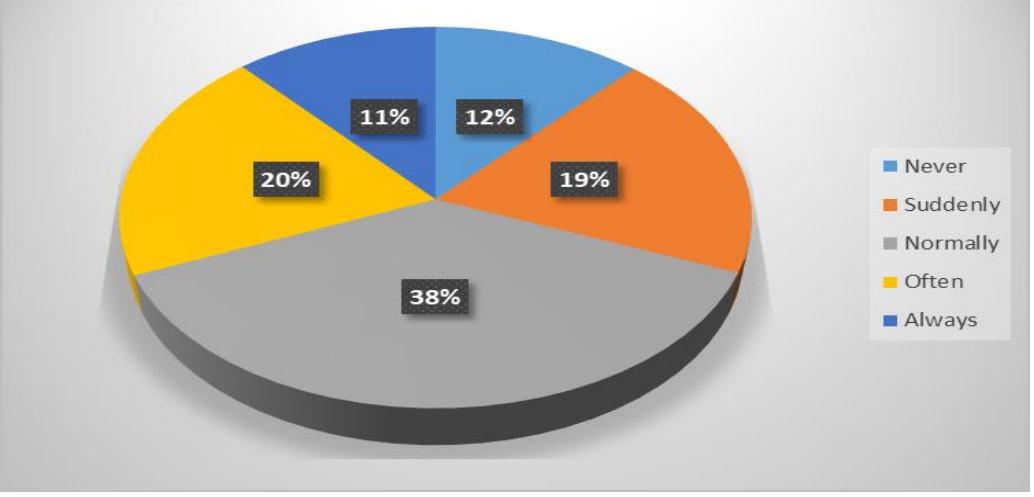

As described in Figure 15, about $64 \%$ of the total sample of students possesses very high levels of skills in operating computers. Only $9 \%$ of the total sample of students has a very low level of skills to operate a computer. Accordingly, $91 \%$ of the students in the sample have sufficient knowledge and skills to operate computers.

Figure 15: Current skills to operate a computer

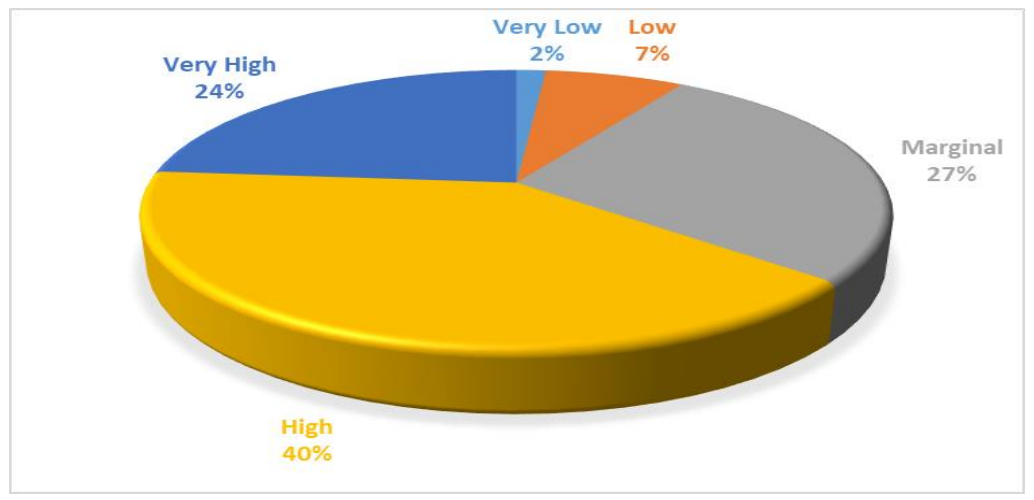

According to the research, $74 \%$ of respondents are members of families with a monthly income of less than Rs. 50,000. Only $6 \%$ of respondents are members of families earning more than Rs.100,000 according to Figure 16. Accordingly, the low monthly family income can be identified as a problem faced in conducting online education in Sri Lanka, which is a developing country. Purchasing equipment for online learning and managing Internet charges depend on this.

Figure 16: Monthly income of the student's family

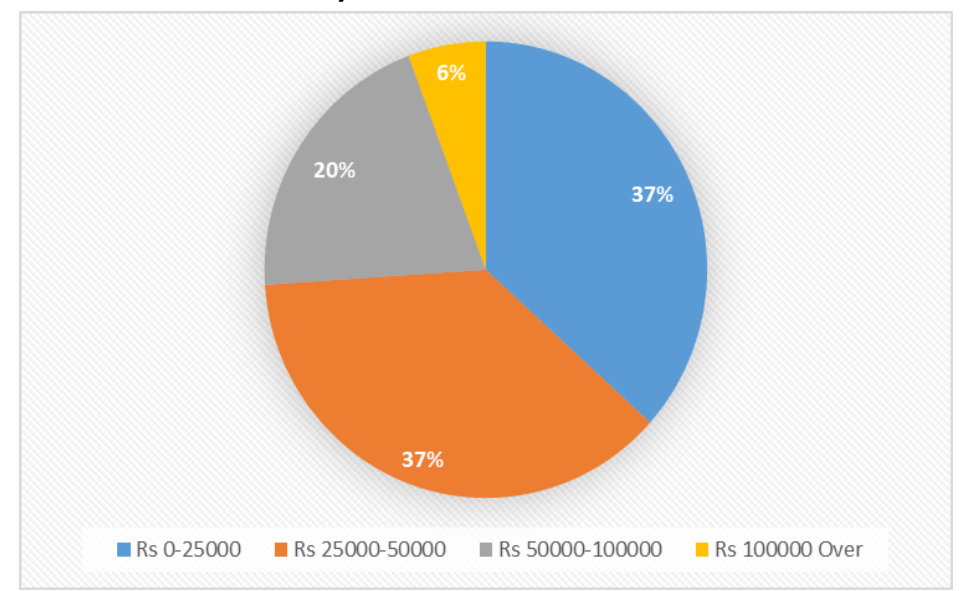

Students' Perception on Online Learning in the Future
A high percentage (nearly $79 \%$ ) of students prefer to use online learning even after this Covid-19 pandemic period and their preference for online learning in the future is shown in Figure 17. 
Figure 17: Student's preference for online learning in the future

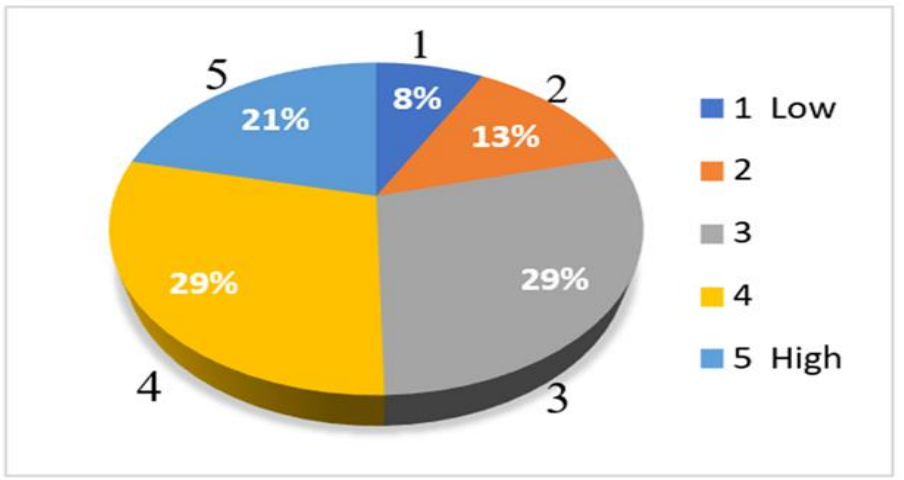

As shown in Figure 18, according to the survey results, students in universities prefer online education to conduct educational activities with university LMS (67\%) and Learn-

Zoom (free usage provided by the government) (55.6\%). It also seems that WhatsApp has become an important mode of communication for online learning instead of other main learning platforms.

Figure18: Students' perception on the future online learning platform

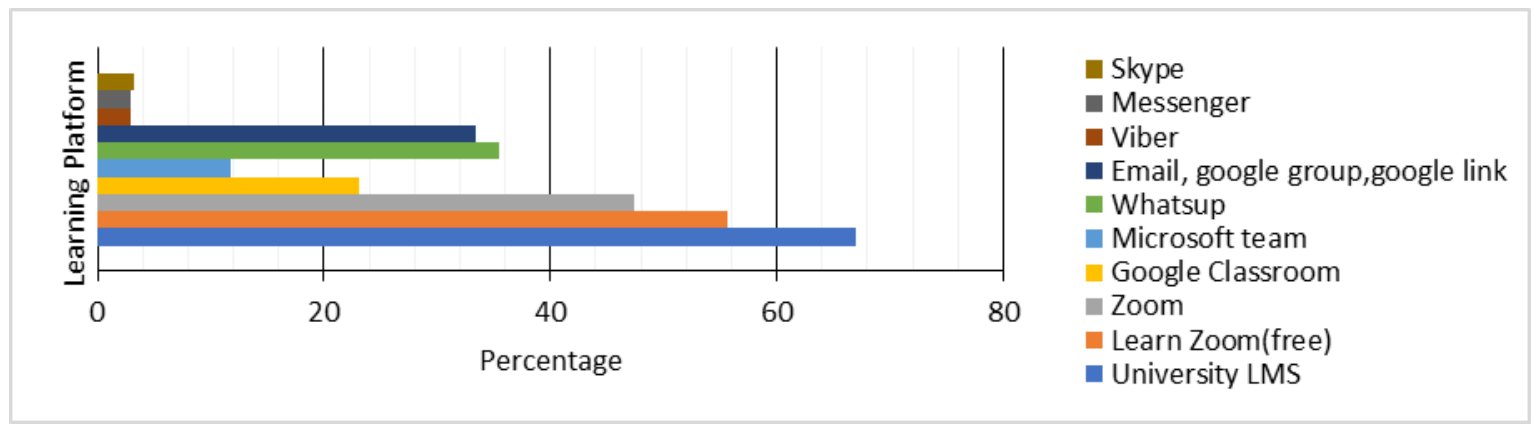

\section{Suggestions for Future Online Education in Sri Lanka}

It is advisable to take the following steps to continue online education even after the coronavirus period. Communications service providers (e.g. Mobitel, Dialog, etc.) should install towers in areas where Internet coverage is poor. It is also advisable to provide loans to university students through commercial banks for the purchase of Laptops, Dongles, WiFi routers, and other equipment required for online education. Actions need to be taken to prevent online education from being disrupted by technical faults, power outages, etc. It is advisable for lecturers to take steps to develop online courses that build closer relationships between the teacher and the student and engage the student activities during online education. It is advisable to repeatedly deliver online lectures. Group assignments should be done during online lectures the relevant authorities should work out a new education system that will enable continuous and productive education under any circumstances.

\section{Evaluation of Research Data Using the Multiple} Regression Analysis

Multiple regression analysis was performed using the MINITAB software. Multiple regression can be used to analyze the data collected for this research as follows. Under this, the multiple regression model is evaluated and the var iability of the coefficients of the variables relevant to the research is checked. The following variables are used for multiple regression.

$\begin{array}{ll}- & \text { Studying University } \\ - & \text { Studying Year } \\ - & \text { Respondents Degree } \\ - & \text { Respondents Gender } \\ - & \text { District of Respondents Home Town } \\ - & \text { Monthly Income } \\ - & \text { Items Use for Online Learning } \\ - & \text { Mode of Connecting to the Internet } \\ - & \text { Internet Coverage in Home Town } \\ - & \text { Data Charge for Online Learning } \\ - & \text { Problems with Recharging Internet Connection } \\ - & \text { Enough Basic Skill to Operate a Computer } \\ - & \text { Enough English Knowledge to Handle Computer } \\ \text { - } & \text { Normal Usage of Social Media or Games } \\ \text { - } & \text { Learning Platforms used During the COVID-19 Pan- } \\ \text { demic } & \\ - & \text { Type of Sharing Lectures/Materials } \\ \text { - } & \text { Confidence in Managing of Online Learning Meth- } \\ \text { ods } & \end{array}$

Of these variables (under $95 \%$ confidence level) not all variables were heterogeneous and only six were heterogeneous as shown in Table 1. 
Table 1: Regression analysis on usage of online learning during Covid-19(Y)

\begin{tabular}{|c|c|c|c|}
\hline Variable & Contribution & P-value & Determine \\
\hline Respondents' Gender & $0.81 \%$ & 0.001 & valid \\
\hline Enough Basic Skills to operate a computer & $9.68 \%$ & 0.004 & valid \\
\hline Enough English Knowledge to handle Computer & $2.07 \%$ & 0.007 & valid \\
\hline Learning platforms used during the COVID-19 pandemic & $6.21 \%$ & 0.0001 & valid \\
\hline Type of sharing lectures/materials & $5.42 \%$ & 0.0001 & valid \\
\hline Confidence to Manage online Learning Methods & $6.48 \%$ & 0.0001 & valid \\
\hline
\end{tabular}

Here the P-value is used to determine whether the association between the response and each term in the model is statistically significant. We have considered the significance level as $0.05(5 \%)$. If the $p$-value for a variable is less than our significance level, we conclude that there is a statistically significant association between the response variable and the term. According to the above results, the variables are statistically significant because the $p$-values are less than the significance level.

The variables that should be used to analyze the usage of online education in the coronavirus period are those with a high level of contribution as well as a good level of probability value. Here, the contribution illustrates how the final format describes the use of online education in the corona period by the chosen variable. In this instance, it is expressed in percentage terms. The higher the value, the higher the analytical suitability of the variable. Further, if the probability value is less than 0.05 , that variable is more suitable for analysis. And these variables are important. Accordingly, the six variables are most appropriate for the analysis of the use of online education in the corona period. The most suitable variables relevant to the research are selected under the Step Wise method.

$Y i=\beta 0+\beta 1 X 1 i+\beta 2 X 2 i+\beta 3 X 3 i+\ldots \ldots+6 i$

(1)
Usage of Online Learning during the Corona Pandemic $(\mathrm{Yi})=$ Constant value $(\beta 0)+(\beta 1)$ Gender $+(\beta 2)$ Enough Basic Skill $+(\beta 3)$ Enough English Knowledge $+(\beta 4)$ Learning methods+ $(\beta 5)$ sharing lectures $+(\beta 6)$ Confidence to Manage Online Learning Methods + ( $\epsilon i)$ Standard error

The following regression equation is constructed by including the most appropriate variables to describe the dependency variable.

Usage of Online Learning during the Corona Pandemic $=0.081-0.2187$ Male +0.244 Low Basic Skill +0.285 Marginal Basic Skill +0.510 High Basic Skill +0.328 Very High Basic Skill -0.031 Poor English Knowledge -0.063 Marginal English Knowledge -0.019 Good English Knowledge +0.309 Excellent English Knowledge +1.790 One of the Methods +1.715 Two of Methods +1.878 Three of Methods +1.847 Four of Methods +1.977 Five of Methods +1.742 Six of Methods +1.737 Seven of Methods +0.486 Eight of Methods +1.701 Nine of Methods +0.515 One of Materials +0.851 Two of Materials +0.651 Three of Materials +0.871 Four of Materials +1.027 Five of Materials +1.059 Six of Materials +1.209 Seven of Materials +0.949 Eight of Materials +1.256 Nine of Materials +0.343 Low Confidence +0,699 Marginal Confidence +0.996 High Confidence +1.258 Very High Confidence (2)

Figure 19: Residuals plots for the usage of online learning during COVID-19

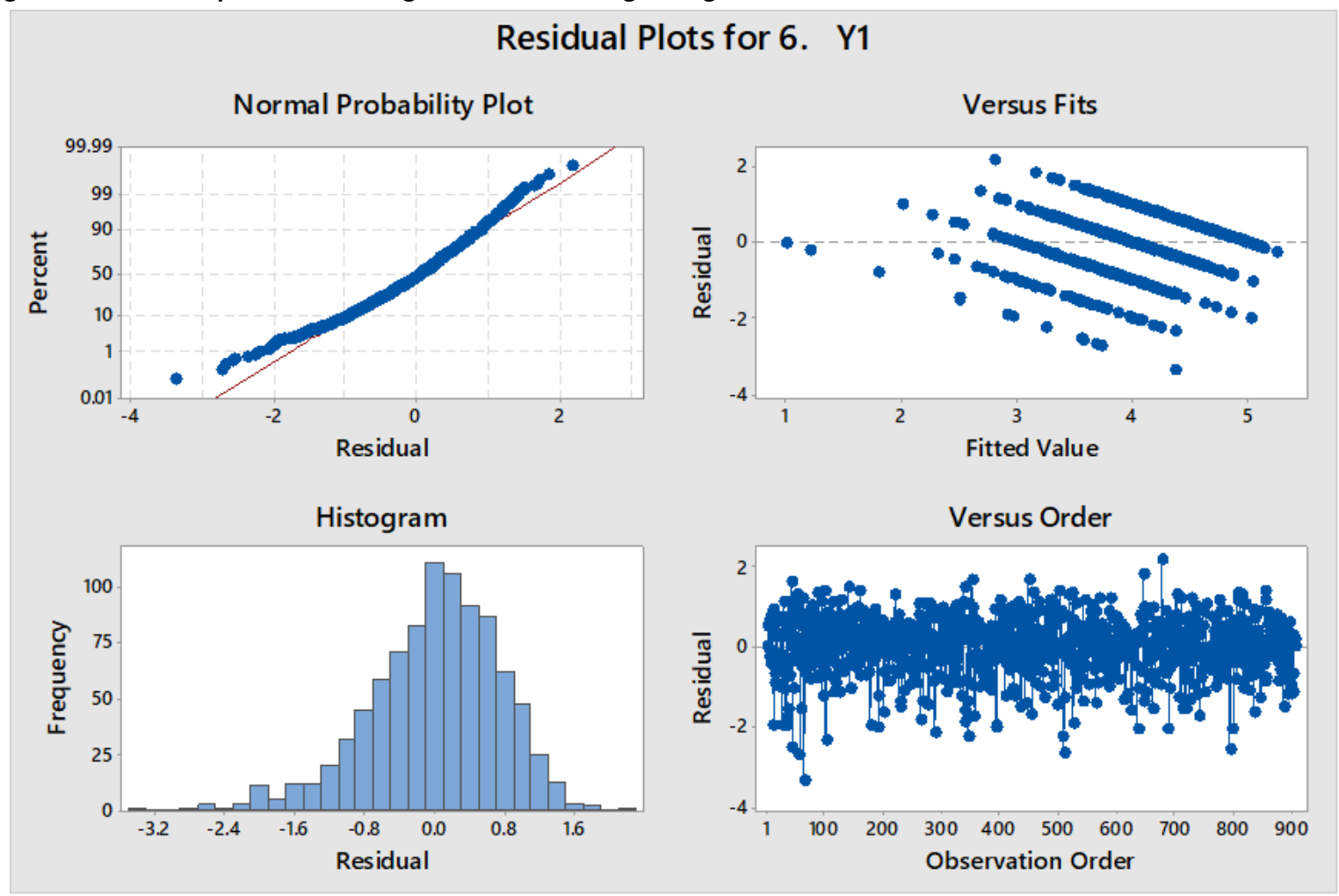

The following information on the research was found in the study of Figure 19 on multiple regression. 
- Normal Probability plot: Residuals for normal probability plot is normal. Because plotted values are plotted on the line.

- Histogram: Residuals are plotted equally around Zero. Plotted values are equally plotted on both sides.

- Versus Fits: Residuals are plotted independently. And also residuals correlate.

- Versus Order: Residuals are randomly distributed. Considering the observations and the error note, it was found that the error terms were scattered randomly without any specific motion.

The behavior of the data in all the diagrams concerning the above error diagram is at an optimal level. That is, it is clear that the research data is from an appropriate data system.

\section{CONCLUSION AND FUTURE WORK}

Public and private university referral to online education has become a timely necessity with the COVID-19 pandemic in Sri Lanka. It is important to consider the response of university students to online education in measuring its effectiveness. The survey covered the public and private universities in Sri Lanka and the conclusion is based on the more than 900 responses received.

Based on the collected data, multiple regression analysis was performed using different variables. According to that result, only six variables were heterogeneous such as respondents' gender, enough basic skills to operate a computer, Enough English knowledge to handle computers, learning platforms used during the COVID-19 pandemic, type of sharing lectures/materials, and confidence to manage online learning methods. It has identified these all six variables are statistically significant and gave a high level of contribution to the study.

According to the results of the normal probability plot, histogram, versus fits, and versus order, we identified that the data in all the diagrams are at an optimal level and the research data is from an appropriate data system.

University students most commonly use smartphones and laptops for online education. Most of them are connected to the Internet through smartphones via WiFi hotspots. Also, during the COVID-19 pandemic, university students have increased the use of university LMS and Zoom as their learning platforms. Zoom is used in private universities depending on a paid system. But state universities have become increasingly popular for online education through Learn-Zoom (free usage). Also, according to the students' responses, WhatsApp usage has become higher for educational communication during the COVID-19 period. And university lecturers conducting online lectures and sharing lecture notes often use PowerPoint to the maximum to deliver their lecture materials.

A high percentage of students prefer to use this kind of online learning in the future after the commencement of universities. The students in universities prefer online education to conduct educational activities with university LMS and Learn-Zoom. As we identified from the research result, those two methods will be more easy and effective methods for online education in the future. Further, university students face several problems with the sudden turn towards online education by the universities. The Internet access problem is the main challenge they are faced with. In some parts of the country, the lack of internet coverage has become a major obstacle for university students to carry out their education. So, lecturers recording their lectures and delivering them to the students is a positive solution to this problem. Even after the COVID-19 pandemic, similar situations may arise. Therefore, even during such cases, university students, as well as lecturers, need to well understand these types of important models and learning platforms for online learning to carry out uninterrupted educational activities. However, the research advises that the time is now to realize the benefits, strengths, and positive impacts of online learning at universities in Sri Lanka.

The above findings of the research are very significant due to the Covid-19 pandemic situation of the country. Not only that there is a possibility to happen this kind of pandemic situations, natural disasters, lockdown situations in the future. So, it is very important to be ready and have a strong online education system for facing those situations without interrupting education. Because of that understanding, the research findings like the suitable online learning model, platform, lecture sharing method, students' problems, and also solutions are very important through this research.

This research does not focus on the adaption of online education of Sri Lankan school students. Therefore, in the future, it is planned to research online education trends in schools by obtaining information from school students and teachers. And it is also hoped to conduct further research on the trend of online education by obtaining information from university lecturers. And also we are planning to improve the research content and analysis part using collected data from undergraduates, lecturers, school teachers as well as school students using more analysis techniques such as KaiserMeyer-Olkin (KMO) test and Bartlett's test.

\section{REFERENCES}

Crawford, J., Butler-Henderson, K., Rudolph, J., Malkawi, B., Glowatz, M., Burton, R., Magni, P., and Lam, S., 2020. COVID-19: 20 countries' higher education intra-period digital pedagogy responses. Journal of Applied Learning \& Teaching, 3(1). https://doi.org/10.37074/jalt.2020.3.1.7

Alipio, M. (2020). Education during Covid-19 Era: Are Learners in a LessEconomically Developed Country Ready for E-Learning? SSRN Electronic Journal. https://doi.org/10.2139/ssrn.3586311

Allen, I. E., \& Seaman, J. (2006). Making the Grade Southern Edition.

Allen, I. E., \& Seaman, J. (2014). Grade change. Tracking Online Education in the United States. Babson Survey Research Group and Quahog Research Group, LLC. https://igencareerpathways.org/teams/curriculum-design/files/gradechange.pdf\%5Cnhttp://www.onlinelearningsurvey.com/reports/gradechange.pdf

Allen, I. E., Seaman, J., Straut, T. T., \& Poulin, R. (2016). Online Report C Ard. 1-62. http://onlinelearningsurvey.com/reports/onlinereportcard.pdf

Allo, M. D. G. (2020). Is online learning good amid Covid-19 Pandemic ? The case of EFL learners. Jurnal Sinestesia, 10(1), 1-10.

Basilaia, G. (2020). Replacing the Classic Learning Form at Universities as an Immediate Response to the COVID-19 Virus Infection in Georgia. International Journal for Research in Applied Science and Engineering Technology, 8(3), 101-108. https://doi.org/10.22214/ijraset.2020.3021

Basilaia, G., \& Kvavadze, D. (2020). Transition to online education in schools during a SARS-CoV-2 coronavirus (COVID-19) pandemic in Georgia. Pedagogical Research, 5(4).

Binti Hamzah, F. A., Lau, C. H., Nazri, H., Ligot, D. C., Lee, G., Tan, C. L., \& et al. (2020). CoronaTracker: Worldwide Covid-19 outbreak data analysis and prediction. Bulletin of the World Health Organization, March, Submitted.

Dziuban, C., Moskal, P., \& Hartman, J. (n.d.). desarrollodocente.uc.cl/images/Innovaci $\tilde{A}^{3}$ /Flipped/Knowledge_is_power_no_more.pdf. Desarrollodocente.Uc.Cl, 1-17. http://desarrollodocente.uc.cl/images/Inno-

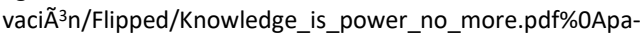
pers3://publication/uuid/5A2403CE-9631-49C0-88CF-56F5E0F37646 
Hayashi, R., Garcia, M., \& Maddawin, A. (2020). Online Learning in Sri Lanka's Higher Education Institutions during the COVID-19 Pandemic DOI: http://dx.doi.org/10.22617/BRF200260-2

Hodges, C., Moore, S., Lockee, B., Trust, T., \& Bond, A. (2020). The Difference Between Emergency Remote Teaching and Online Learning. Educause Review.

Hou, H., Lv, W., Tao, Q., Hospital, T., Company, J. T., Ai, T., Hospital, T., Wuhan, T., Hospital, T., Butt, C., Gill, J., Chun, D., Babu, B. A., Zhao, J., Zhang, Y., He, X., \& Xie, P. (2020). Pr es s In Pr. Applied Intelligence, 2019, 1-5. https://doi.org/10.1007/s10489-020-01714-3

Merkl-Davies, Doris M.; Brennan, N. (2001). Provided by the author(s) and University College Dublin Library by publisher policies. Please cite the published version when available. Discretionary disclosure strategies incorporate narratives : incremental information or impression ma. The Irish Journal of Psychology, 32(1-2), 4-13. https://doi.org/http://dx.doi.org/10.1680/geot.2008.T.003

Moorhouse, B. L. (2020). Adaptations to a face-to-face initial teacher education course 'forced' online due to the COVID-19 pandemic. Journa of Education for Teaching, 00(00), 1-3. https://doi.org/10.1080/02607476.2020.1755205

Morse, K. (2007). "Learning on Demand." The Challenges of Educating People to Lead in a Challenging World, 33-49. https://doi.org/10.1007/978-1-4020-5612-3_2

Mulenga, E. M., \& Marbán, J. M. (2020). Is COVID-19 the Gateway for Digital Learning in Mathematics Education? Contemporary Educa tional Technology, 12(2), ep269. https://doi.org/10.30935/cedtech/7949

Murphy, M. P. A. (2020). COVID-19 and emergency eLearning: Consequences of the securitization of higher education for post-pandemic pedagogy. Contemporary Security Policy, 41(3), 492-505. https://doi.org/10.1080/13523260.2020.1761749

Plancher, K. D., Shanmugam, J. P., \& Petterson, S. C. (2020). The Changing Face of Orthopedic Education: Searching for the New Reality After
COVID-19. Arthroscopy, Sports Medicine, and Rehabilitation. https://doi.org/10.1016/j.asmr.2020.04.007

Platt, L. D. (2003). Staying the course. Ultrasound in Obstetrics and Gynecology, 21(1), 13-14. https://doi.org/10.1002/uog.35

Putri, S. E., Hamuddin, B., Nursafira, M. S., \& Derin, T. (2020). Discourse Analysis in E-Learning-Based Course Using Moodle Platform: An Experimental Design. REiLA : Journal of Research and Innovation in Language, 2(1), 19-26. https://doi.org/10.31849/reila.v2i1.3960

Trung, T., Hoang, A. D., Nguyen, T. T., Dinh, V. H., Nguyen, Y. C., \& Pham, H. H. (2020). Dataset of Vietnamese student's learning habits during COVID-19. Data in Brief, 30, 105682. https://doi.org/10.1016/j.dib.2020.105682

UNESCO. (2020, Maret 4). 290 million students out of school due to COVID-19: UNESCO releases first global numbers and mobilizes response. Dipetik April 13, 2020, dari UNESCO: https://en.unesco.org/news/290-million-students-out-school-duecovid-19-unesco-releases-first-global-numbers-and-mobilizes

Yan, C. H., Faraji, F., Prajapati, D. P., Boone, C. E., \& DeConde, A. S. (2020). Association of chemosensory dysfunction and Covid-19 in patients presenting with influenza-like symptoms. International Forum of Allergy and Rhinology, OO(0), 1-8. https://doi.org/10.1002/alr.22579

Yang, C. L., Qiu, X., Zeng, Y. K., Jiang, M., Fan, H. R., \& Zhang, Z. M. (2020). Coronavirus disease 2019: A clinical review. European Review for Medical and Pharmacological Sciences, 24(8), 4585-4596. https://doi.org/10.26355/eurrev_202004_21045

YukiKogyo Co.Ltd, D. integrity issue. (2019). No TitleEAENH. Ayan, 8(5), 55.

Zu, Z. Y., Jiang, M. Di, Xu, P. P., Chen, W., Ni, Q. Q., Lu, G. M., \& Zhang, L. J. (2020). Coronavirus Disease 2019 (COVID-19): A Perspective from China. Radiology, 296(2), E15-E25. https://doi.org/10.1148/radiol.2020200490

Annexures

Annexure 01: Regression Analysis

Interpreting the results:

Degrees of freedom (DF), Sum of Squares (SS), Mean Squared Errors (MS), and F-value can be used to determine whether the test is statistically significant.

R-squared (R-sq), Predicted R-squared (R-sq (pred)), Adjusted R-squared (R-sq(adj)), Predicted Residual Error Sum of Squares (PRESS), Standard error of the regression (S)

Categorical predictor coding $(1,0), \alpha$ to enter $=0.25$

Analysis of Variance:

\begin{tabular}{|c|c|c|c|c|c|c|}
\hline Source & DF & Seq SS & Contribution & Adj SS & Adj MS & F-Value \\
\hline Regression & 55 & 261.320 & $33.87 \%$ & 261.320 & 4.7513 & 7.94 \\
\hline 1. Your university & 16 & 26.663 & $3.46 \%$ & 13.752 & 0.8595 & 1.44 \\
\hline 4. Your gender & 1 & 7.940 & $1.03 \%$ & 5.413 & 5.4133 & 9.04 \\
\hline 2. Mode of connecting to the I & 4 & 19.236 & $2.49 \%$ & 6.770 & 1.6924 & 2.83 \\
\hline 4. Data charge (bill of internet & 4 & 17.339 & $2.25 \%$ & 5.382 & 1.3456 & 2.25 \\
\hline 6. Do you have enough basic ski & 4 & 49.373 & $6.40 \%$ & 8.261 & 2.0651 & 3.45 \\
\hline 7. Do you think your English is & 4 & 14.425 & $1.87 \%$ & 7.643 & 1.9108 & 3.19 \\
\hline 1. What kind of methods you use & 9 & 39.782 & $5.16 \%$ & 15.925 & 1.7694 & 2.96 \\
\hline 2. What type of lectures/materials & 9 & 37.721 & $4.89 \%$ & 29.795 & 3.3105 & 5.53 \\
\hline 3. How about your confidence to & 4 & 48.841 & $6.33 \%$ & 48.841 & 12.2103 & 20.39 \\
\hline Error & 852 & 510.129 & $66.13 \%$ & 510.129 & 0.5987 & \\
\hline Lack-of-Fit & 832 & 510.129 & $66.13 \%$ & 510.129 & 0.6131 & $*$ \\
\hline Pure Error & 20 & 0.000 & $0.00 \%$ & 0.000 & 0.0000 & \\
\hline Total & 907 & 771.448 & $100.00 \%$ & & & \\
\hline
\end{tabular}

\begin{tabular}{|l|l|}
\hline Source & P-Value \\
\hline Regression & 0.000 \\
\hline 1. Your university & 0.118 \\
\hline 4. Your gender & 0.003 \\
\hline 2. Mode of connecting to the I & 0.024 \\
\hline
\end{tabular}




\begin{tabular}{|l|l|}
\hline 4. Data charge (bill of internet & 0.062 \\
\hline 6. Do you have enough basic ski & 0.008 \\
\hline 7. Do you think your English is & 0.013 \\
\hline 1. What kind of methods you use & 0.002 \\
\hline 2. What type of lectures/material & 0.000 \\
\hline 3. How about your confidence to & 0.000 \\
\hline Error & \\
\hline Lack-of-Fit & $*$ \\
\hline Pure Error & \\
\hline Total & \\
\hline
\end{tabular}

Model Summary:

\begin{tabular}{|l|l|l|l|l|}
\hline S & R-sq & R-sq(adj) & PRESS & R-sq(pred) \\
\hline 0.773785 & $33.87 \%$ & $29.61 \%$ & $*$ & $*$ \\
\hline
\end{tabular}

Regression Equation:

\begin{tabular}{|c|c|c|}
\hline 6. Y1 & $=$ & 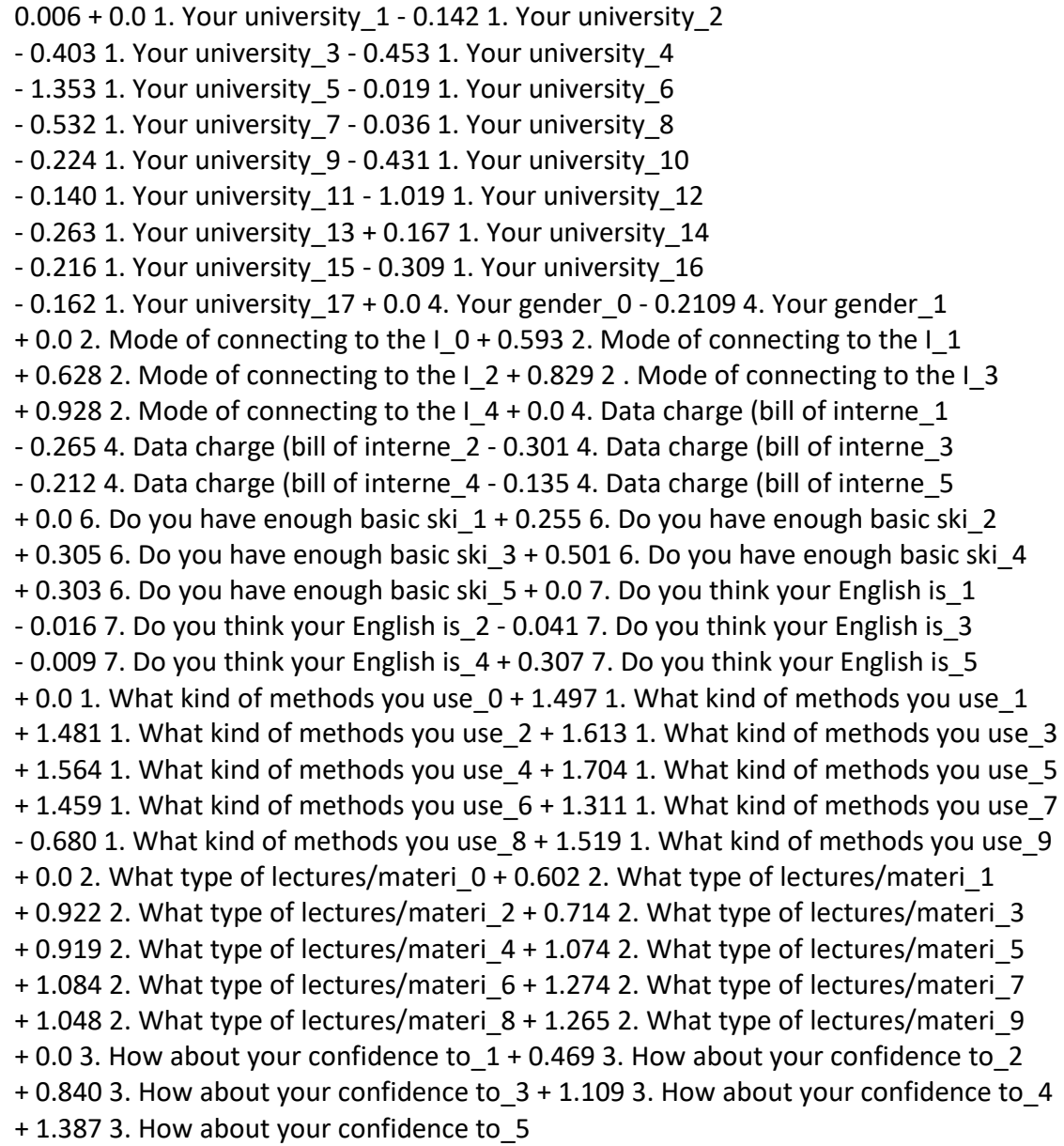 \\
\hline
\end{tabular}

